Article

\title{
Butyrate Stimulates Histone H3 Acetylation, 8-Isoprostane Production, RANKL Expression, and Regulated Osteoprotegerin Expression/Secretion in MG-63 Osteoblastic Cells
}

\author{
Mei-Chi Chang ${ }^{1,2,+}{ }^{,}$Yunn-Jy Chen ${ }^{3, \dagger}{ }^{+}$Yun-Chia Lian ${ }^{2}$, Bei-En Chang ${ }^{4}$, Chih-Chia Huang ${ }^{5}$, \\ Wei-Ling Huang ${ }^{2}$, Yu-Hwa Pan ${ }^{2,6, *}$ and Jiiang-Huei Jeng ${ }^{3, *}$ \\ 1 Chang Gung University of Science and Technology, Kwei-Shan, Taoyuan 333, Taiwan; \\ mcchang@mail.cgust.edu.tw \\ 2 Department of Dentistry, Chang Gung Memorial Hospital, Taipei Branch, 6th Floor, 199, Tung-Hwa North \\ Road, Taipei 105, Taiwan; yunyun445@cgmh.org.tw (Y.-C.L.); weiwei0110@hotmail.com (W.-L.H.) \\ 3 School of Dentistry and Department of Dentistry, National Taiwan University Hospital and National Taiwan \\ University Medical College, Taipei 100, Taiwan; chenyj@ntu.edu.tw \\ 4 Graduate Institute of Oral Biology, National Taiwan University Medical College, Taipei 100, Taiwan; \\ beien@ntu.edu.tw \\ 5 Department of Dentistry, Cardinal Tien Hospital, New Taipei City 234, Taiwan; frank554@ms13.hinet.net \\ 6 Graduate Department of Craniofacial Dentistry, Chang-Gung University Medical College, \\ Taoyuan 333, Taiwan \\ * Correspondence: Shalom.dc@msa.hinet.net (Y.-H.P.); jhjeng@ntu.edu.tw (J.-H.J.); \\ Tel.: +886-2-27135211 (ext. 3535) (Y.-H.P.); +886-2-23123456 (ext. 67755) (J.-H.J.) \\ + These authors contributed equally to this work.
}

Received: 6 December 2018; Accepted: 14 December 2018; Published: 17 December 2018

\begin{abstract}
Butyric acid as a histone deacetylase (HDAC) inhibitor is produced by a number of periodontal and root canal microorganisms (such as Porphyromonas, Fusobacterium, etc.). Butyric acid may affect the biological activities of periodontal/periapical cells such as osteoblasts, periodontal ligament cells, etc., and thus affect periodontal/periapical tissue destruction and healing. The purposes of this study were to study the toxic effects of butyrate on the matrix and mineralization marker expression in MG-63 osteoblasts. Cell viability was determined by 3-(4,5-dimethylthiazol-2-yl)-2,5-diphenyl tetrazolium bromide (MTT) assay. Cellular apoptosis and necrosis were analyzed by propidium iodide/annexin $\mathrm{V}$ flow cytometry. The protein and mRNA expression of osteoprotegerin (OPG) and receptor activator of nuclear factor kappa-B ligand (RANKL) were analyzed by Western blotting and reverse transcriptase-polymerase chain reaction (RT-PCR). OPG, soluble RANKL (sRANKL), 8-isoprostane, pro-collagen I, matrix metalloproteinase-2 (MMP-2), osteonectin (SPARC), osteocalcin and osteopontin (OPN) secretion into culture medium were measured by enzyme-linked immunosorbant assay. Alkaline phosphatase (ALP) activity was checked by ALP staining. Histone $\mathrm{H} 3$ acetylation levels were evaluated by immunofluorescent staining (IF) and Western blot. We found that butyrate activated the histone H3 acetylation of MG-63 cells. Exposure of MG-63 cells to butyrate partly decreased cell viability with no marked increase in apoptosis and necrosis. Twenty-four hours of exposure to butyrate stimulated RANKL protein expression, whereas it inhibited OPG protein expression. Butyrate also inhibited the secretion of OPG in MG-63 cells, whereas the sRANKL level was below the detection limit. However, 3 days of exposure to butyrate (1 to $8 \mathrm{mM}$ ) or other HDAC inhibitors such as phenylbutyrate, valproic acid and trichostatin stimulated OPG secretion. Butyrate stimulated 8-isoprostane, MMP-2 and OPN secretion, but not procollagen I, or osteocalcin in MG-63 cells. Exposure to butyrate (2-4 mM) for 3 days markedly stimulated osteonectin secretion and ALP activity. In conclusion, higher concentrations of butyric acid generated by periodontal and root canal microorganisms may potentially induce
\end{abstract}


bone destruction and impair bone repair by the alteration of OPG/RANKL expression/secretion, 8-isoprostane, MMP-2 and OPN secretion, and affect cell viability. However, lower concentrations of butyrate (1-4 mM) may stimulate ALP, osteonectin and OPG. These effects are possibly related to increased histone acetylation. These events are important in the pathogenesis and repair of periodontal and periapical destruction.

Keywords: bone resorption; butyric acid; HDAC inhibitor; osteoblasts; osteoprotegerin/RANKL; periodontal/root canal pathogens

\section{Introduction}

Butyrate is a well-known histone deacetylase (HDAC) inhibitor [1]. Butyric acid can be generated by microorganisms present in the dental plaque and biofilms of the root surface and root canals, and is involved in the pathogenesis of periodontitis and apical periodontitis. Periodontal and root canal (dental pulp) pathogens, such as Porphyromonas gingivalis (P. gingivalis) and other microorganisms, are widely distributed in the periodontal pocket, root canal and apical lesion of the root apex [2-7]. These pathogenic microorganisms are able to attack and invade adjacent tissues or release toxic metabolites such as endotoxin, proteases and short chain fatty acids (e.g., propionic acid, and butyric acid) which affect cellular responses [6-8].

Recent studies have found that butyrate plays an important role in periodontal and apical lesions in the gums and periodontal tissues. The concentrations of butyric acid may reach $0.2-16 \mathrm{mM}$ in the gingival sulcus $[9,10]$, and the concentration of butyric acid in root canals decreases after endodontic treatment [11]. Butyric acid may affect the biological activities of periodontal/periapical cells such as osteoblasts, periodontal ligament cells, gingival fibroblasts (GF) and inflammatory cells, etc., [12-14], thus affecting periodontal/periapical tissue destruction and healing.

Bone homeostasis depends on the balance of bone resorption by osteoclasts and formation by osteoblasts. An imbalance of bone turnover may cause diseases such as osteoporosis, bone resorption, periodontitis, etc. [15]. Interactions between osteoblasts and osteoclasts via direct contact or cytokine release is important for bone homeostasis. Osteoblasts may affect osteoclast activity through the osteoprotegerin (OPG)/receptor activator of nuclear factor kappa-B (RANK)/RANK ligand (RANKL) system [15]. An increase in RANK, RANKL and OPG expression in the progression of periodontitis and apical periodontitis has been reported [16-18]. An increased ratio of RANKL/OPG can be a marker showing the presence of periodontitis and bone resorption [18]. These changes in expression of OPG and RANKL during periodontitis may be related to the presence of various periodontal and root canal pathogens $[19,20]$ and related toxins. P. gingivalis lipopolysaccharide (LPS) has been shown to affect RANKL and RANKL/OPG ratios of periodontal ligament fibroblasts [21]. However, limited information is known about butyric acid on the OPG and RANKL expression of osteoblastic cells and their possible contribution to periodontal bone destruction.

Previously, we have found that butyrate suppresses adhesion, cell growth and protein synthesis, but induces reactive oxygen species and the cell cycle arrest of gingival fibroblasts (GF) [12,22]. It also inhibited cell growth, collagen I expression, and induced cell cycle arrest and the p21 and p27 expression of osteoblasts [23]. The purposes of this study was to further study the effects of butyrate on bone metabolism and turnover mediated by the alteration of OPG/RANKL mechanisms and other matrix/mineralization molecules. Understanding these effects and mechanisms can help us with the treatment and prevention of subsequent periodontal and periapical diseases. 


\section{Results}

\subsection{Stimulation of Histone H3 Acetylation by Butyrate}

Control MG63 cells showed limited nuclear staining of Ac-H3 (Figure 1A). Butyrate (8 mM) stimulated the histone $\mathrm{H} 3$ acetylation of MG-63 cells as analyzed by immunofluorescent (IF) staining. An increase in the red fluorescence of nuclear staining of MG-63 cells was noted after 120 min of exposure to $8 \mathrm{mM}$ butyrate (Figure 1A). An increase in Ac-H3 nuclear staining was also noted when MG-63 cells were exposed to butyrate for $24 \mathrm{~h}$ (Figure 1B). Accordingly, butyrate stimulated the Ac-H3 expression of MG-63 cells as analyzed by Western blotting (Figure 1C).

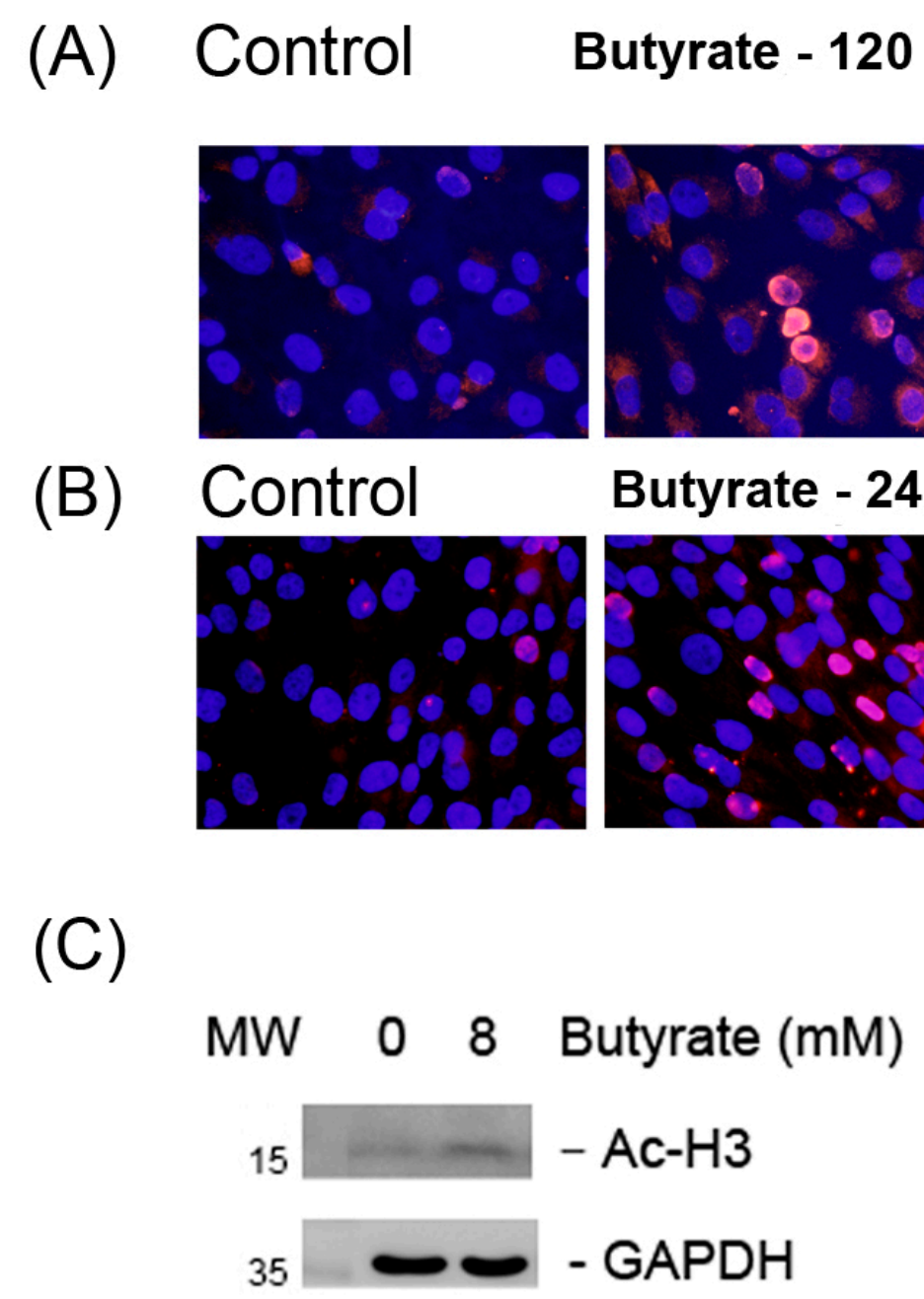

Figure 1. The stimulation of the histone $\mathrm{H} 3$ acetylation of MG63 cells as analyzed by immunofluorescent staining (IF) and Western blotting. (A) IF pictures of Ac-H3 expression: Control (120 min) and butyrate $(8 \mathrm{mM})$-treated MG-63 cells for $120 \mathrm{~min}$. (B) IF pictures of Ac-H3 expression: Control $(24 \mathrm{~h})$ and butyrate $(8 \mathrm{mM}$ )-treated MG63 cells for $24 \mathrm{~h}, 400 \times$, original magnification, (C) Western blotting of control and $8 \mathrm{mM}$ butyrate-treated MG-63 cells for $24 \mathrm{~h}$. One representative IF study result was shown. GADPH: Glyceroaldehyde-3-dehydrogenase. MW: Molecular weight (KD).

\subsection{Morphology of MG-63 Cells after Exposure to Butyrate for Three Days}

When non-confluent MG-63 cells $\left(1 \times 10^{4}\right.$ cells/well) were cultured for three days, cells grew to confluence. MG-63 cells were fibroblast-like in appearance (Figure $2 \mathrm{~A})$. When exposed to butyrate (4 and $8 \mathrm{mM}$ ) for three days, the cell density of MG-63 cells slightly decreased (Figure 2B,C). Exposure 
to $16 \mathrm{mM}$ for three days further decreased the cell density, with spaces between cells suggesting an increasing toxicity of butyrate (Figure 2D).
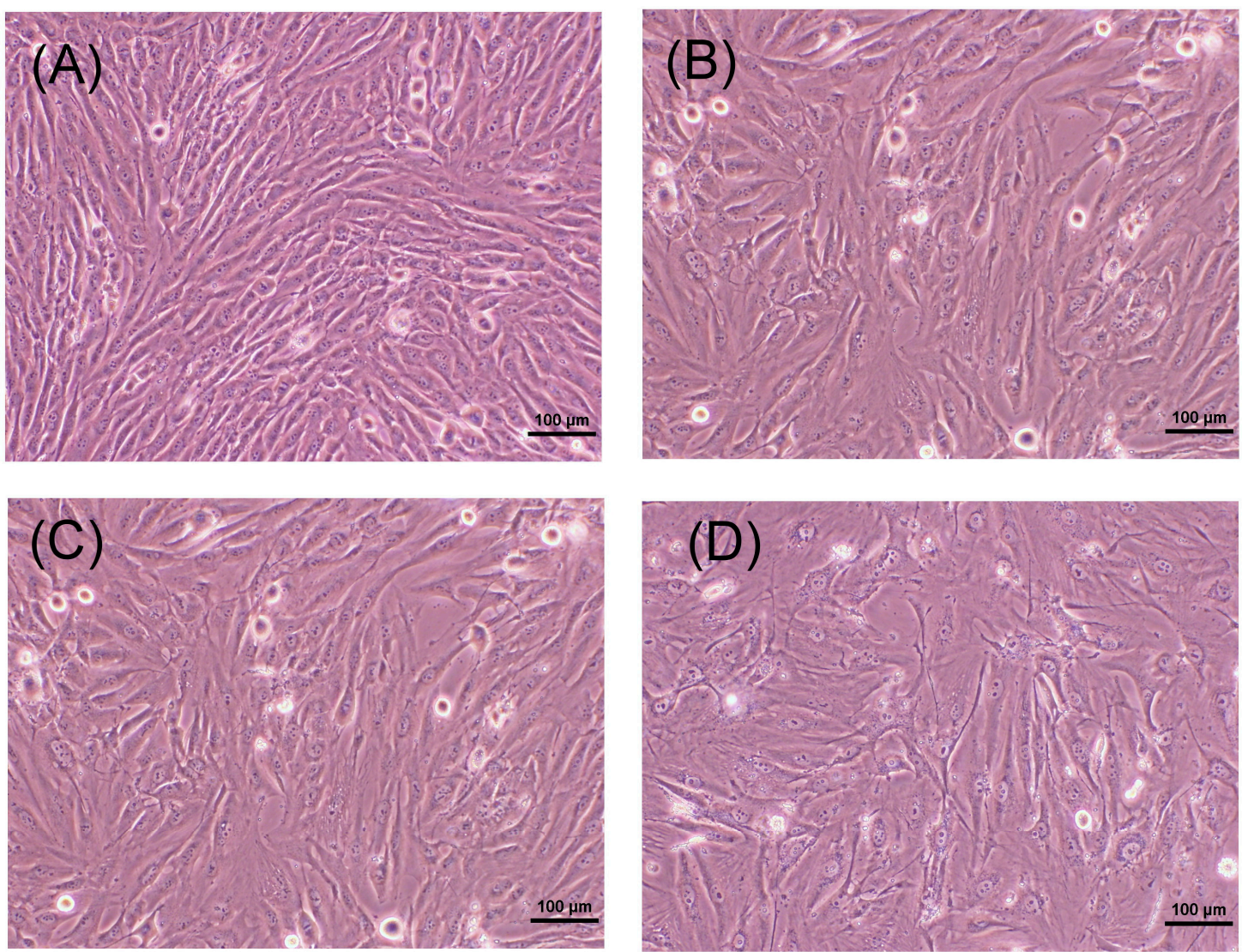

Figure 2. Morphologic changes of MG-63 cells ( $10^{4}$ cells/well) after exposure to different concentrations of butyrate for three days. (A) Control, (B) $4 \mathrm{mM}$ butyrate, (C) $8 \mathrm{mM}$ butyrate, (D) $16 \mathrm{mM}$ butyrate. $100 \times$ original magnification $(\mathrm{bar}=100 \mu \mathrm{m})$. One representative result was shown.

\subsection{Effect of Butyrate on the Growth and Cell Viability of MG-63 Cells}

Accordingly, when non-confluent MG-63 cells $\left(1 \times 10^{4}\right.$ cells/well) were exposed to butyrate $(16$ and $24 \mathrm{mM}$ ) for three days, cell viability decreased (Figure 3A). On the other hand, when confluent MG-63 cells $\left(1 \times 10^{5}\right.$ cells/well) were exposed to butyrate for three days, cell viability showed no marked difference (Figure 3B). 

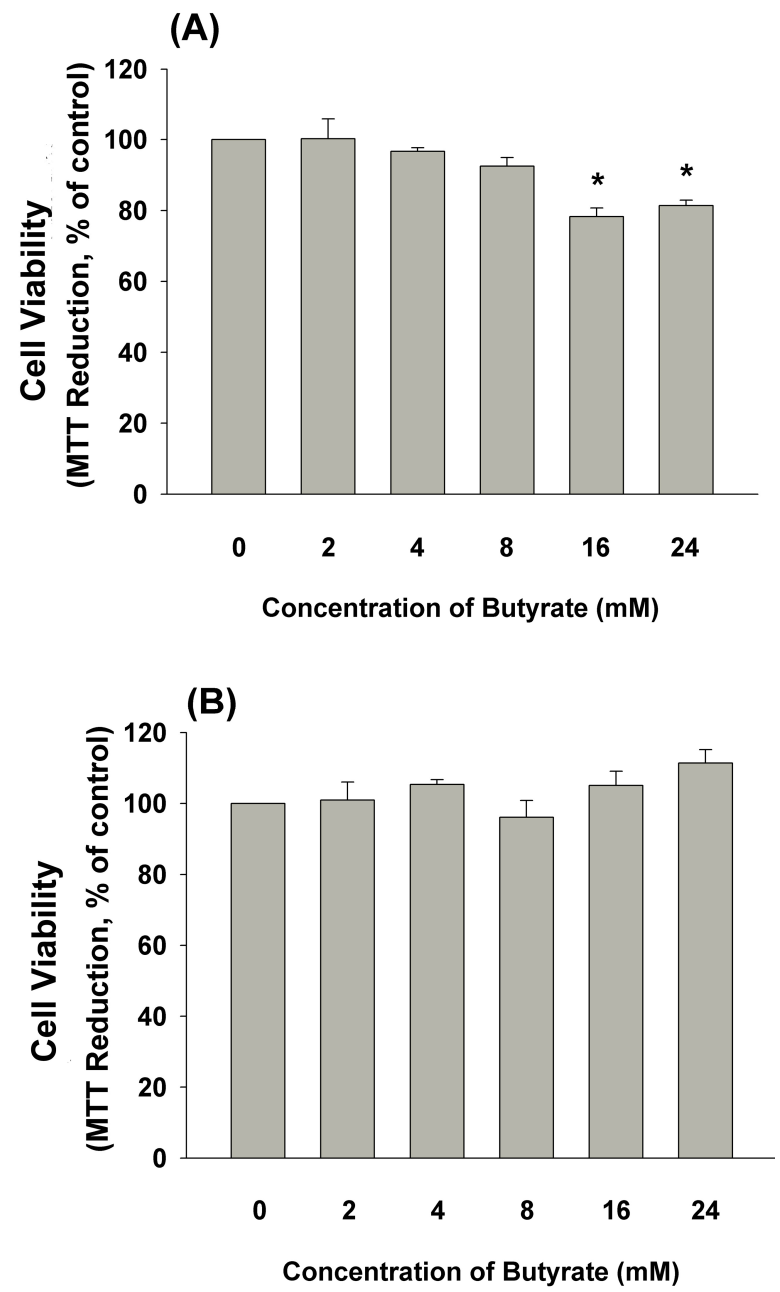

Figure 3. Effect of butyrate on the cell viability of MG63 cells: (A) MG63 cells $(1 \times 10,000$ cells/24-well) were exposed to butyrate for 3 days, (B) roughly confluent MG63 cells $(1 \times$ 100,000 cells / 24 -well) were exposed to butyrate for three days. Cell viability was determined by 3-(4,5-dimethylthiazol-2-yl)-2,5-diphenyl tetrazolium bromide (MTT) assay. Results were expressed as a percentage of control (Mean $\pm \mathrm{SE}$ ). Statistically significant difference when compared with the control $(p<0.05)$ denoted by *.

\subsection{Effect of Butyrate on the Apoptosis and Necrosis of MG-63 Cells}

Propidium iodide (PI) and annexin V flow cytometric analysis was used to determine the induction of apoptosis and necrosis of MG-63 cells after exposure to various concentrations of butyrate. As shown in Figure 4A, exposure to $16 \mathrm{mM}$ butyrate could not evidently induce apoptosis (upper right (UR) \& lower right (LR)) and necrosis (upper left (UL)) of MG-63 cells. Quantitatively, the percentage of cells (\%) residing in the UL (necrotic cells) increased from $4.19 \%$ to $4.79 \%$ after exposure to $24 \mathrm{mM}$ butyrate. In addition, the percentage of cells in the UR (apoptotic cells) and LR (pro-apoptotic cells) quadrants changed from $0.85 \%$ and $0.41 \%$ in the control to $1.28 \%$ and $1.05 \%$, respectively, with $16 \mathrm{mM}$ butyrate (Figure 4B, Table 1). 


\section{(A) control}

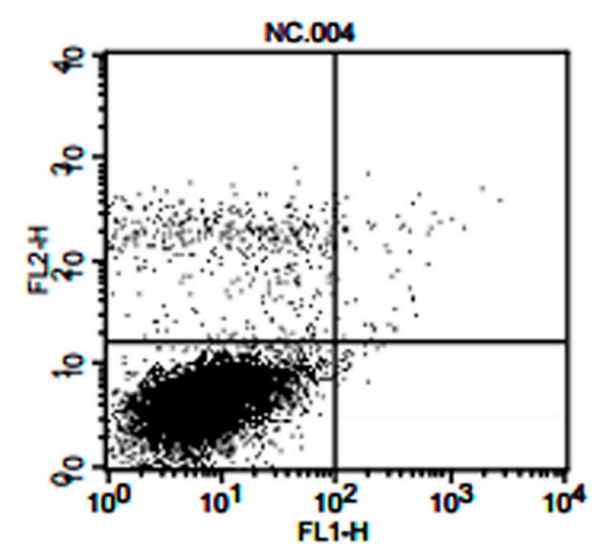

Fine: NC.004

\begin{tabular}{crr} 
Quad & \% Gated & \% \\
\hline UL & 5.84 & 5.84 \\
UR & 0.56 & 0.56 \\
LL & 93.38 & 93.38 \\
LR & 0.22 & 0.22
\end{tabular}

\section{(B) $16 \mathrm{mM}$ butyrate}

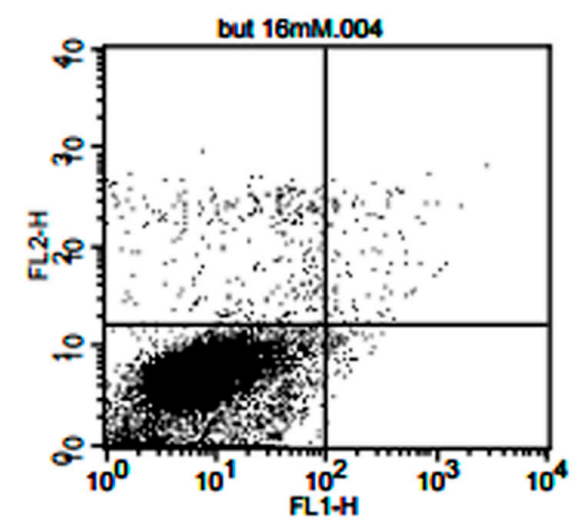

File: but $16 \mathrm{mM} .004$

\begin{tabular}{crr} 
Quad & \% Galed & \% \\
\hline UL & 4.62 & 4.62 \\
UR & 0.92 & 0.92 \\
LL & 93.83 & 93.83 \\
LR & 0.63 & 0.63
\end{tabular}

Figure 4. Effect of butyrate on the induction of the apoptosis and necrosis of MG63 cells as analyzed by propidium iodide (PI) + annexin V flow cytometry. UL (upper left): Necrosis, UR (upper right) and LR (lower right): Apoptosis. One representative PI and annexin V flow cytometry histogram was shown.

(A) Control and (B) $16 \mathrm{mM}$ butyrate-treated cells.

Table 1. Induction of apoptosis and necrosis of MG63 cells by various concentrations of butyrate as analyzed by PI and annexin V flow cytometry $(n=4)$. No statistically significant difference was noted between groups. LL (lower left).

\begin{tabular}{ccccc}
\hline Quadrant & Control & $\mathbf{8} \mathbf{~ m M}$ Butyrate & 16 mM Butyrate & 24 mM Butyrate \\
\hline UR & $0.85 \pm 0.10$ & $1.25 \pm 0.19$ & $1.28 \pm 0.2$ & $1.43 \pm 0.40$ \\
UL & $4.19 \pm 1.12$ & $4.19 \pm 0.57$ & $4.24 \pm 0.51$ & $4.79 \pm 0.33$ \\
LR & $0.41 \pm 0.06$ & $0.86 \pm 0.21$ & $1.05 \pm 0.30$ & $0.75 \pm 0.24$ \\
LL & $94.54 \pm 1.05$ & $93.69 \pm 0.31$ & $93.41 \pm 0.18$ & $93.02 \pm 0.36$ \\
\hline
\end{tabular}

\subsection{Effect of Butyrate on OPG and RANKL $m R N A$ and Protein Expression}

The exposure of MG-63 cells to butyrate for 24 h stimulated RANKL mRNA expression (>1 mM), whereas it inhibited OPG mRNA expression as analyzed by RT-PCR (Figure 5A), and thus decreased the ratio of OPG/RANKL. Butyrate also stimulated RANKL protein expression ( $>4 \mathrm{mM})$. On the contrary, it inhibited OPG protein expression $(>1 \mathrm{mM})$ as analyzed by Western blotting (Figure 5B). 
(A)

Concentration of Butyrate

$\begin{array}{llllllll}M & 0 & 1 & 2 & 4 & 8 & 16 & (\mathrm{mM})\end{array}$

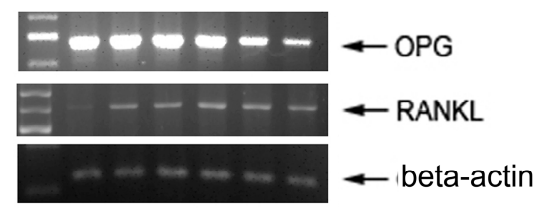

(B)

Concentration of Butyrate

$\begin{array}{lllllll}M & 0 & 1 & 2 & 4 & 8 & 16\end{array}$

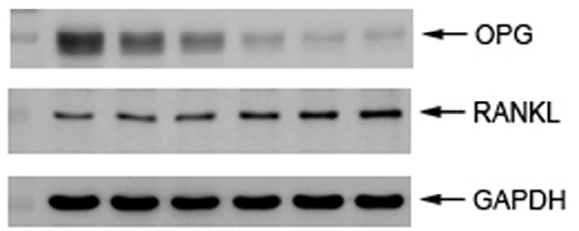

(C)

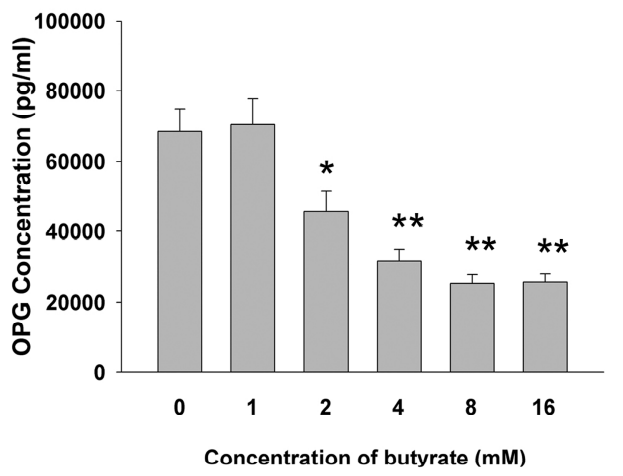

Figure 5. Effect of 24-h exposure to butyrate on the osteoprotegerin (OPG) and receptor activator of nuclear factor kappa-B ligand (RANKL) expression of MG63 osteoblastic cells. (A) RT-PCR analysis of mRNA expression, (B) Western blot analysis of OPG and RANKL protein expression, (C) ELISA analysis of OPG level in culture medium. Statistically significant differences are denoted by * and ** $(p<0.05$ and $p<0.01)$ when compared with the control, respectively.

\subsection{Effect of Butyrate on OPG and RANKL Secretion of MG-63 Cells}

Since OPG and RANKL are important for the regulation of bone resorption, we further determined whether the exposure of MG-63 cells to butyrate may affect the secretion of OPG and RANKL. Interestingly, butyrate markedly inhibited the secretion of OPG in MG-63 cells at concentrations ranging from $2-16 \mathrm{mM}$ after $24 \mathrm{~h}$ of exposure (Figure 5C). Unexpectedly, the sRANKL level in the culture medium was below the detection limit (data not shown).

\subsection{Effect of 3 days of Exposure of MG-63 Cells to Butyrate or other HDAC Inhibitors on OPG Secretion}

The exposure of MG-63 cells to butyrate for 3 days stimulated OPG secretion, with a maximal stimulation at about 1 to $4 \mathrm{mM}$ (Figure 6A). Similarly, phenylbutyrate (1 to $8 \mathrm{mM}$ ) as an HDAC inhibitor also stimulated OPG secretion. However, this effect became less evident at $16 \mathrm{mM}$, possibly due to toxicity (Figure 6B). Valproic acid as the other HDAC inhibitor also induced the OPG production of MG-63 cells at concentrations ranging from 0.5 to $2 \mathrm{mM}(p<0.05)$ or higher $(4 \mathrm{mM}, p=0.06)$ (Figure $6 \mathrm{C})$. 
Moreover, trichostatin also stimulated the OPG secretion of MG-63 cells at concentrations of 0.5 and $1 \mu \mathrm{M}$. However, the marked suppression of OPG secretion of MG- 63 cells by 5 and $10 \mu \mathrm{M}$ of trichostatin was noted, possibly due to cytotoxicity (Figure 6D).

(A)

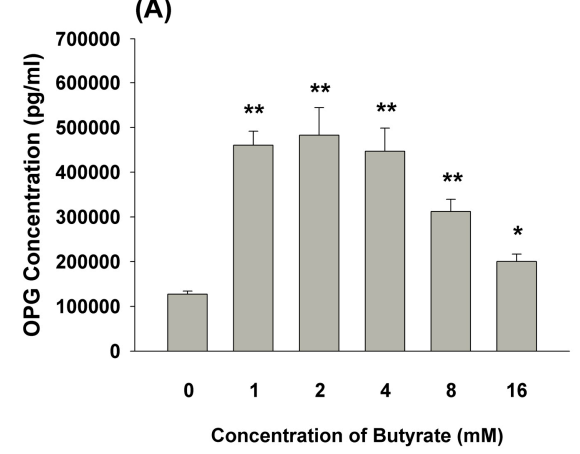

(C)

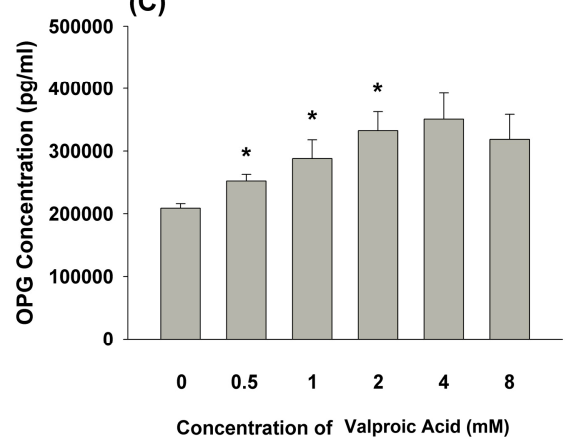

(B)

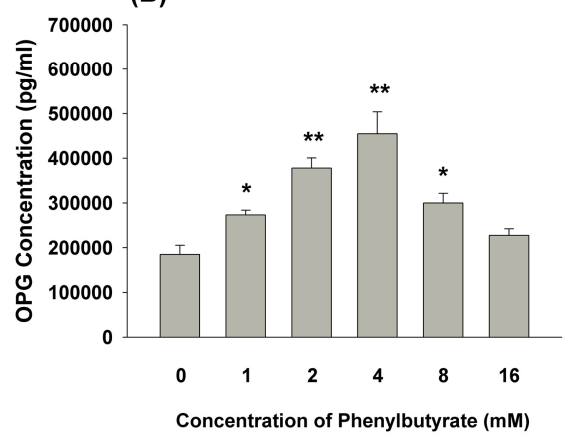

(D)

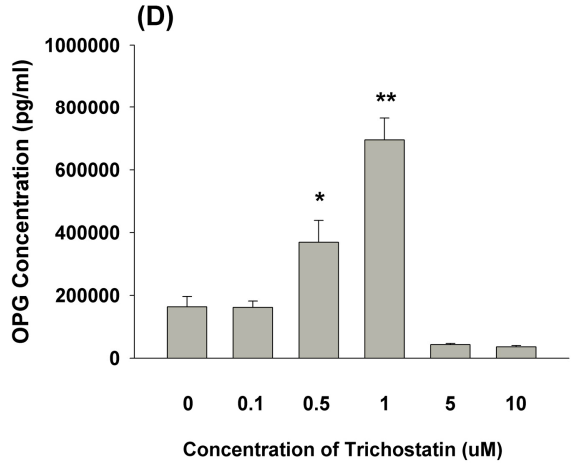

Figure 6. OPG secretion of MG-63 cells after three days of exposure to (A) butyrate, (B) phenylbutyrate, (C) valproic acid, (D) trichostatin for three days. The OPG level in the culture medium was determined by ELISA and expressed as mean $\pm \mathrm{SE}(\mathrm{pg} / \mathrm{mL})$. Statistically significant differences are denoted by * and ${ }^{* *}(p<0.05$ and $p<0.01)$ when compared with the control, respectively.

2.8. Effect of Butyrate on 8-Isoprostane, Pro-Collagen I, MMP-2, Osteopontin, Osteonectin, and Osteocalcin Secretion as well as the ALP Activity of MG-63 Cells

Exposure to butyrate significantly stimulated the 8-isoprostane production of MG63 cells (Figure 7A). For matrix turnover, butyrate showed no marked effect on pro-collagen 1a1 secretion after $24 \mathrm{~h}$ of exposure (Figure $7 \mathrm{~B})$. On the other hand, butyrate $(>1 \mathrm{mM})$ induced the MMP-2 secretion of MG-63 cells (Figure 7C), and butyrate (2 to $4 \mathrm{mM}$ ) showed a mild stimulatory effect on osteonectin (SPARC) secretion (Figure 7D). For mineralization markers, butyrate showed little stimulatory effect on the osteocalcin production of MG-63 cells (Figure 7E). Moreover, butyrate ( $>24 \mathrm{mM}$ ) evidently stimulated the osteopontin (OPN) secretion of MG63 cells (Figure 7F). Interestingly, butyrate stimulated the ALP activity of MG-63 cells, with maximal stimulation at about 2 to $4 \mathrm{mM}$ as revealed by ALP staining (Figure 7G). 


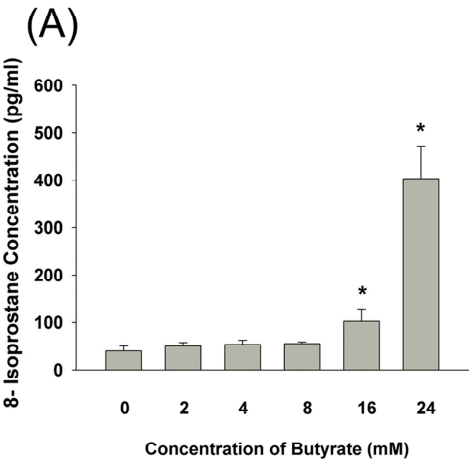

(C)

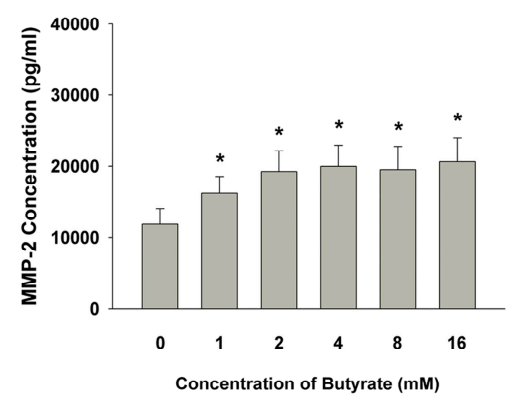

(E)

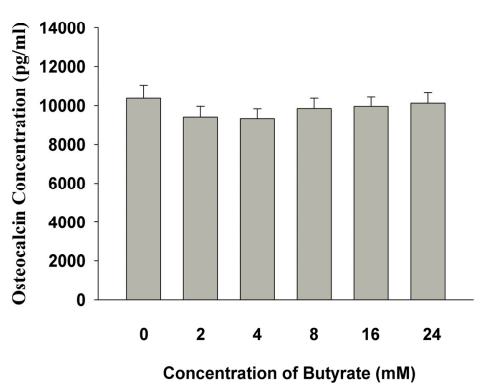

(B)

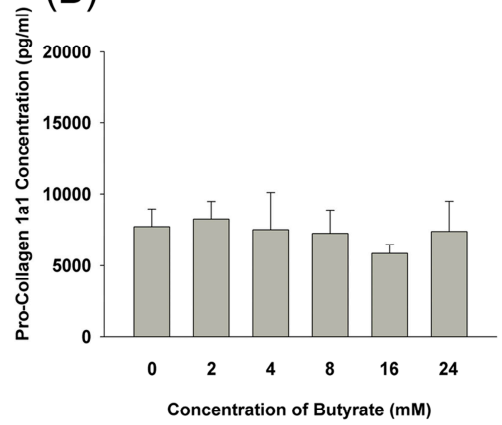

(D)

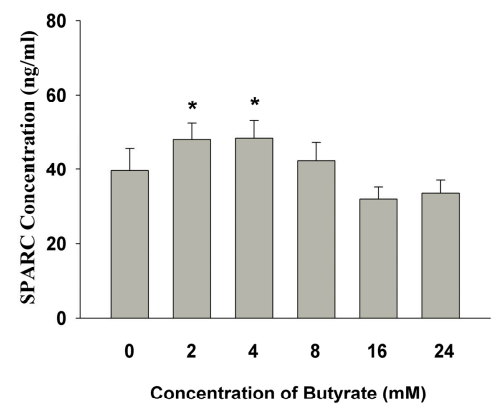

$(\mathrm{F})$

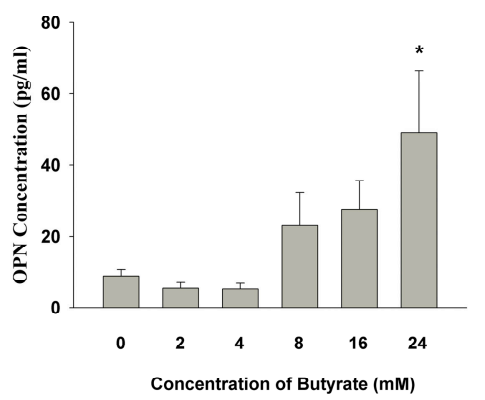

(G)

\section{Concentration of Butyrate $(\mathrm{mM})$}

$\begin{array}{llllll}0 & 1 & 2 & 4 & 8 & 16\end{array}$

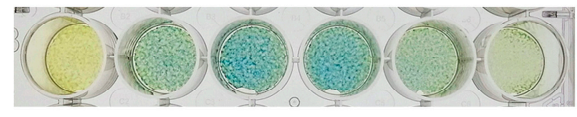

Figure 7. Effect of three days of exposure to butyrate on (A) 8-isoprostane, (B) pro-collagen I, (C) MMP-2, (D) osteonectin, (E) osteocalcin, and (F) osteopontin (OPN) secretion of MG-63 cells as analyzed by ELISA. Results were expressed as mean \pm SE. Statistically significant differences are denoted by * when compared with the control $(p<0.05)$. (G) Effect of butyrate on the alkaline phosphatase (ALP) activity of MG-63 cells. One representative ALP staining picture was shown.

\section{Discussion}

Butyrate is a well-known histone deacetylase (HDAC) inhibitor produced by microorganisms of the oral cavity and intestinal tract. Short chain fatty acids (SCFA) including propionic acid and butyric acid may contribute to periodontal/periapical tissue toxicity [3,14]. The levels of SCFA may reach 
0.2-16 mM in gingival crevicular fluid (GCF), and periodontal treatment decreases the concentrations of SCFA in GCF $[9,10,14]$, suggesting the important role of SCFA in periapical/periodontal diseases. Possibly, SCFA may induce an inflammatory response and affect the viability and biological activities of periodontal and periapical tissues, leading to bone destruction. In this study, butyrate inhibited cell viability, but showed no appreciable cytotoxicity to near-confluent MG-63 cells, indicating that the presence of higher concentrations of butyrate in the periodontal pocket or root canal may potentially impair the clinical tissue healing response. Similarly, butyrate suppressed the adhesion, growth and protein synthesis of gingival epithelial cells and fibroblasts. It also induced the death and cytokine release of inflammatory cells $[9,12,14,22]$. However, the inhibition of cell viability by butyrate is not mediated by apoptotic and necrotic cell death. Butyrate induces a minimal apoptotic and necrotic effect on MG-63 cells as analyzed by propidium iodide (PI) and annexin V flow cytometry. Other studies have reported the induction of apoptosis on colon cancer cells, B cells and other kinds of cells by butyrate $[1,24,25]$, showing the effect of butyrate may vary by cell type. Ho \& Chang (2007) further discovered the toxicity of butyrate on dental pulp cells and its relation to glutathione (GSH) depletion [26]. Interestingly, butyrate showed a possible toxicity for proliferating MG-63 cells, which increases proportionally with the concentration of butyrate. The actual reasons and meanings for different results with butyrate are unclear and await further investigation.

SCFAs have inflammatory and anti-inflammatory effects depending on the cells and conditions [27,28]. As an HDAC inhibitor, butyrate may stimulate histone acetylation [1]. Interestingly, butyrate is shown to attenuate the tumor necrosis factor- $\alpha$ (TNF- $\alpha$ and LPS-induced interleukin- 6 (IL-6) expression of endothelial cells via the activation of GPR41/GPR43 receptors. However, the prevention of TNF- $\alpha$ and LPS-induced IL- 8 expression of endothelial cells by butyrate is related to its inhibition of histone deacetylase (HDAC), but not its activation of GPR receptors [29]. Butyrate stimulates the differentiation of mesenchymal stem cells to smooth muscle cells or osteoblasts by enhancing histone $\mathrm{H} 3$ and $\mathrm{H} 4$ acetylation, and the down-regulation of HDAC2 or MEK/ERK-Runx2 signaling [30,31]. In this study, butyrate also induced the histone H3 acetylation of MG-63 osteoblasts, implicating the possible involvement of histone acetylation by butyrate in periodontal destruction and healing. Recently, the stimulation of histone acetylation by HDAC inhibitors such as trichostatin A, butyrate, and valproic acid has been shown to promote osteoblast maturation and bone formation [32]. During osteoblast differentiation, histones $\mathrm{H} 3$ and $\mathrm{H} 4$ are hyperacetylated. The knockdown of HDAC1 by siRNA also promotes osteoblast differentiation [33]. These results suggest the possible effect of butyrate on bone turnover.

Previous study has found butyrate causes the stimulation of the reactive oxygen species (ROS) production of MG-63 cells [23]. 8-isoprostane (8-iso-prostaglandin F2 $\alpha$ ), as an oxidative stress marker and lipid peroxidation product, is generated by the free-radical catalyzed peroxidation of essential fatty acids such as arachidonic acid to stimulate redox-sensitive signaling pathways and transcriptional factors [34-36]. Isoprostanes may mediate vasoconstriction, tissue inflammation, perception of pain, vascular reperfusion, paracetamol poisoning, liver cirrhosis, atherosclerosis and cancer [34,35,37]. Limited information is known about the generation of isoprostanes by osteoblasts and their roles in bone turnover. In this study, 8-isoprostane as an oxidative stress marker was also found to be stimulated in MG-63 cells by butyrate, suggesting the induction of lipid peroxidation by butyrate. This may partly explain the elevated salivary, GCF or root canal 8-isoprostane level in patients with periodontitis, pulpitis or chronic apical periodontitis [38-41], suggesting the involvement of increased oxidative stress in pulpal/periapical pain, periodontal and periapical bone destruction. It has been found that iso-PGE 2 but not iso- $\mathrm{PGF}_{2}$ alpha had an inhibitory effect on the induction of alkaline phosphatase activity in MC3T3-E1 preosteoblasts [42]. Urinary F2-isoprostanes levels have been found to show a negative correlation with bone mineral content and bone mineral density [43]. It has been found that patients with diabetes, obesity, hypercholesterolemia, smokers, etc., have higher levels of urinary isoprostane [44]. Possibly, urinary isoprostane levels can be used as marker of periodontal 
and periapical diseases in the future. An increase of 8-isoprostane by butyrate may be involved in the pathogenesis of periodontal/periapical diseases.

Bone turnover is tightly regulated by the interaction of osteoblasts and osteoclasts [15], possibly via the OPG/RANKL system. It has been shown that periodontal/root canal pathogens may stimulate the RANKL expression of bone marrow cells $[19,20]$. Injection of anti-RANKL and osteoprotegerin fusion protein into rat gingiva may attenuate the bone resorption induced by $P$. gingivalis infection [20]. $P$. gingivalis LPS is shown to stimulate RANKL and increase the RANKL/OPG ratio in periodontal ligament fibroblasts [21]. An increased expression of RANK, RANKL and OPG during the progression of periodontitis and apical periodontitis has been reported [16]. Belibasakis et al. (2013) also found the protective role of OPG against root resorption and the increased apical RANKL/OPG ratio in bone resorption [17]. The level of RANKL is found to be increased, but the OPG level is decreased, in severe periodontitis [45]. Cyst and granuloma tissues from periapical lesions also show an increased expression of RANKL and the importance of RANKL and OPG products in apical bone destruction [17,46-48]. However, butyrate is shown to stimulate OPG expression in normal human osteoblasts [49]. In this study, butyrate was shown to stimulate RANKL, but decrease OPG expression and the secretion of osteoblasts, within $24 \mathrm{~h}$ of exposure. This may partly explain why butyric acid may be involved in periodontal and periapical bone destruction and turnover. However, exposure to lower concentrations of butyrate $(<8 \mathrm{mM})$ for three days was shown to stimulate OPG secretion, suggesting that exposure time and concentrations of butyric acid in the gingival sulcus and apical region may affect the tissue healing responses. Moreover, phenylbutyrate, valproic acid and trichostatin, three HDAC inhibitors, also stimulated the OPG secretion of MG-63 cells, showing the possible involvement of histone acetylation in this event.

While mesenchymal stem cells are known to become flattened, spread and to differentiate into osteoblasts [50], butyrate is shown to affect the differentiation of colon cancer cells and osteoblastic cells $[1,24,49,51]$. Butyrate $(0.1 \mathrm{mM})$ stimulates the expression of mineralization markers in periodontal ligament cells, whereas butyrate exhibits cytotoxicity at concentrations higher than $1 \mathrm{mM}$ [52]. Butyrate $(0.1 \mathrm{mM})$ stimulates calcium content, mineralized nodule formation and the expression of bone sialoprotein (BSP), osteopontin (OPN) and OPG, but showed little effect on proliferation, M-CSF, type I collagen expression and the ALP activity of normal human osteoblasts [49]. It seems that butyrate mainly affects osteoblasts in the late stage of differentiation rather than osteoblasts at the early stage. It also stimulates ALP activity in MC3T3 osteoblasts [51]. Butyrate stimulates bone sialoprotein (BSP) expression in rat ROS17/2.8 osteoblast-like cells [1]. BSP may function in the initial mineralization stage of bone and is crucial for osteoblast differentiation, bone matrix mineralization and tumor metastasis [1]. On the contrary, butyrate $(1 \mathrm{mM})$ suppressed the expression of Runx2, Osterix, Dlx5, Msx2, osteocalcin, ALP and BSP expression as well as mineralized nodule formation in ROS17/2.8 osteoblasts [13]. Similarly, butyrate (0.1-1 mM) also stimulates cyclooxygenase-2 (COX-2), collagen, OPN, EP1, and EP2 prostaglandin E2 receptor expression and PGE2 production, but showed little effect on the proliferation of ROS17/2.8 cells [53]. In this study, butyrate stimulated MMP-2 and OPN at higher concentrations, but showed no marked stimulatory effect on the pro-collagen I and osteocalcin (SPARC) of MG63 osteoblastic cells. At concentrations of 1-4 mM, it may stimulate ALP activity and osteonectin secretion. These results suggest that butyrate may affect the matrix turnover and differentiation of osteoblastic cells. Given the wide heterogeneity, the differential results of butyrate may be related to differences in cell types, such as primary cultures of rats, other cells from murine bone tissue, other cells from immortalized cultures, osteosarcoma cells and also those from clinical studies, etc. Other factors including differentiation status (pre-osteoblasts and osteoblasts), butyrate concentration, exposure time, and cell density may also affect the results and clinical responses of apical/periodontal tissues to butyric acid.

We have previously found that propionate and butyrate may affect the activities including the growth, attachment, migration, reactive oxygen species and cell cycle alteration of gingival fibroblasts and osteoblasts $[12,22,23]$. In conclusion, the exposure of MG-63 osteoblastic cells to butyrate leads 
to histone $\mathrm{H} 3$ acetylation and 8-isoprostance production. Butyrate inhibited cell viability but did not induce the apoptosis of MG-63 osteoblasts. Higher concentrations of butyrate further stimulate MMP-2, OPN and RANKL but inhibit OPG expression and secretion, affecting the matrix turnover and mineralization of bone tissues. Lower concentrations of butyrate may stimulate ALP and osteonectin. These results may increase our understanding of the role of butyric acid in the pathogenesis of apical and periodontal bone destruction and can be helpful for disease prevention and treatment in the future.

\section{Materials and Methods}

\subsection{Materials}

Dulbecco's modified Eagle's medium (DMEM), fetal bovine serum (FBS), trypsin/EDTA, and penicillin/streptomycin were from Gibco (Life Technologies, Grand Island, NY, USA). Antibodies of glyceroaldehyde-3-dehydrogenase (GAPDH) were purchased from Santa Cruz, whereas antibodies for Ac-H3, OPG and RANKL were from GeneTex. Ethidium bromide, agarose and kits for reverse transcription (RT) and polymerase chain reaction (PCR) were purchased from HT Inc., UK. Total RNA isolation kits were from Qiagen Inc. (Santa Clarita, CA, USA). Specific PCR primer sets were synthesized by Genemed Biotechnologies, Inc. (San Francisco, CA, USA). Protein assay kits were obtained from Bio-Rad (Bio-Rad Labs, Hercules, CA, USA). Sodium butyrate was obtained from Sigma (Sigma-Aldrich Company, St. Louis, MO, USA). MG-63 cells were obtained from the American Type Culture Collection (ATCC). OPG, RANKL, pro-collagen I, MMP-2, osteopontin, osteocalcin and osteonectin (SPARC) ELISA kits were from R\&D. 8-Isoprostane ELISA kits were from Cayman.

\subsection{Immunofluorescent Staining of Ac-H3 Expression}

MG-63 cells $\left(1 \times 10^{5}\right)$ were seeded onto a 24-well culture with sterile coverslips in $1 \mathrm{~mL}$ DMEM with $10 \%$ FBS. After $24 \mathrm{~h}$, a culture medium containing various concentrations of butyrate (1-16 mM) was added and cells were further incubated for $24 \mathrm{~h}$. MG-63 cells were also exposed to $8 \mathrm{mM}$ butyrate for different time points (5-120 min). The medium was removed, cells were washed with PBS and fixed in $4 \%$ paraformaldehyde for $20 \mathrm{~min}$. Cells were further washed with PBS, permeabilized with $2 \%$ Triton $\mathrm{X}-100$, and exposed to $0.3 \% v / v \mathrm{H}_{2} \mathrm{O}_{2}$ for $20 \mathrm{~min}$. After rinsing with $\mathrm{PBS}, 5 \%$ bovine serum albumin (BSA) was used for blocking the nonspecific sites for $1 \mathrm{~h}$, and then cells were incubated with primary antibodies (acetyl-histone $\mathrm{H} 3)(1: 1000, v / v$, as $0.1 \mu \mathrm{g} / \mathrm{mL})$ at room temperature overnight. Following washing by PBS, cells were incubated in tetramethylrhodamine (TRITC)-conjugated secondary antibodies in the dark for $1 \mathrm{~h}$ and the nucleus was counterstained with DAPI (1:1000, at $5 \mu \mathrm{g} / \mathrm{mL}$ ) for $30 \mathrm{~min}$. Finally, the cells on coverslips were mounted and photographed/observed under an inverted microscope and DP Controller/Manager software (Olympus IX71, Olympus Corporation, Tokyo, Japan) [23,54].

\subsection{Effect of Butyrate on the Proliferation and Viability of MG-63 Cells}

Briefly, cells were plated into 24 -well culture plates at a density of $1 \times 10^{4}$ or $1 \times 10^{5}$ cells /well. Cells were exposed to fresh medium containing various concentrations of butyrate $(2,4,8,16$ and $24 \mathrm{mM}$ ) for $24 \mathrm{~h}$ or 3 days. The morphology of cells was taken under a microscope. Cell viability was estimated by MTT assay as before [22,23].

\subsection{Inducing the Apoptosis and Necrosis of MG-63 Cells by Butyrate: PI and Annexin V Flow Cytometric Analysis}

Briefly, $5 \times 10^{5}$ cells in a 6-well culture plate were exposed to $2 \mathrm{~mL}$ fresh medium containing different concentrations of butyrate $(2,4,8,16$ and $24 \mathrm{mM})$ for $24 \mathrm{~h}$. Annexin V/PI dual staining flow cytometric analysis was conducted as previously $[55,56]$. In short, both the floating and attached cells were harvested. Cells were then washed with PBS, resuspended in $400 \mu \mathrm{L}$ (4-(2-hydroxyethyl)-1-piperazineethanesulfonic acid) and (HEPES, $10 \mathrm{mM}-\mathrm{NaOH}, \mathrm{pH}$ 7.4, $140 \mathrm{mM}$ 
$\mathrm{NaCl}, 2.5 \mathrm{mM} \mathrm{CaCl}_{2}$ ) solution, the annexin V-fluorescein isothiocyanate (FITC, Becton Dickson, Franklin Lakes, NJ, USA)) / PI ( $50 \mu \mathrm{g} / \mathrm{mL})$ staining solution was added, and the cells were incubated in the dark for $30 \mathrm{~min}$. The annexin V-FITC and PI fluorescence of cells were measured by FACSCalibur Flow Cytometry (Becton Dickinson) immediately after. For the analysis of each sample, 15,000 events were recorded. The fluorescence of the cells of samples was gated and counted. The percentage of cell localization in the upper right (apoptotic), upper left (necrotic cells), lower right (pro-apoptotic cells), and lower left (control) portion of the histogram was determined for comparison.

\subsection{Effect of Butyrate on the mRNA Expression of OPG, RANKL of Cultured MG-63 Cells}

About $1 \times 10^{6}$ MG-63 cells in $10 \mathrm{~cm}$ culture dishes were exposed in fresh medium containing butyrate $(1,2,4,8,16 \mathrm{mM})$. Total RNA was isolated using Qiagen RNA isolation kits. Semi-quantitative reverse-transcriptase and polymerase chain reaction (RT-PCR) was performed as follows: In brief, $3 \mu \mathrm{g}$ of denatured total RNA was reverse-transcribed in a total volume of $44.5 \mu \mathrm{L}$ reaction mixture containing $4 \mu \mathrm{L}$ of random primer $(500 \mu \mathrm{g} / \mathrm{mL}), 8 \mu \mathrm{L}$ of dNTP $(2.5 \mathrm{mM}), 4.5 \mu \mathrm{L}$ of $10 x$ RT buffer, $1 \mu \mathrm{L}$ of RNase inhibitor $(40 \mathrm{U} / \mu \mathrm{L})$ and $0.5 \mu \mathrm{L}$ of RT $(21 \mathrm{U} / \mu \mathrm{L})$ at $42{ }^{\circ} \mathrm{C}$ for 90 minutes. Four microliters of cDNA were then used for PCR amplification in a reaction volume of $50 \mu \mathrm{L}$ containing $5 \mu \mathrm{L}$ of $10 \times$ Super TAQ buffer, $4 \mu \mathrm{L}$ of dNTP $(2.5 \mathrm{mM}), 1 \mu \mathrm{L}$ of each specific primer, and $0.2 \mu \mathrm{L}$ of Super TAQ enzyme $(2 \mathrm{U} / \mu \mathrm{L})$. The reaction mixture was initially heated to $94^{\circ} \mathrm{C}$ for 5 minutes in the first cycle, then the reaction was amplified for $15-35$ cycles of $94{ }^{\circ} \mathrm{C}$ for $30 \mathrm{~s}, 55^{\circ} \mathrm{C}$ for $30 \mathrm{~s}$ and then $72{ }^{\circ} \mathrm{C}$ for $30 \mathrm{~s}$ with a thermal cycler (Perkin Elmer 4800, PE Applied Biosystems, Foster city, CA, USA). Finally, the reaction was set at $72{ }^{\circ} \mathrm{C}$ for a further $10 \mathrm{~min}$.

Specific primer sets for OPG-TCAAGCAGGAGTGCAATCG and AGAATGCCTCCTCA CACAGG—and RANKL—CCAGCATCAAAATCCCAAGT and CCCCTTCAGATGATCCTTC—with PCR amplified products of 342 and 603 base pairs, respectively, were used [57]. An expression of beta-actin was used as a control [58]. The amplified DNA products are loaded onto $1.8 \%$ of agarose gel in $1 \times$ of Tris/Borate/EDTA (TBE) buffer for electrophoresis. Gels were stained with ethidium bromide and photographs were taken. The range of amplified DNA product that was linear in relation to the input RNA was used for data presentation. The amplification of the BAC gene is used as a control.

\subsection{Effects of Butyrate on OPG, RANKL and Ac-H3 Protein Expression of MG-63 Cells}

MG-63 cells $\left(1 \times 10^{6}\right.$ cells $)$ in 10-cm culture dishes were exposed to fresh medium containing various concentrations of butyrate $(1,2,4,8,16 \mathrm{mM})$ for $24 \mathrm{hrs}$. Cell lysates were collected as described previously using freshly prepared lysis buffer $(10 \mathrm{mM}$ Tris-HCl, $\mathrm{pH} 7 ; 140 \mathrm{mM}$ sodium chloride; $3 \mathrm{mM}$ magnesium chloride; $0.5 \%$ NP-40; $2 \mathrm{mM}$ phenylmethylsulfonyl fluoride; $1 \%$ aprotinin; and $5 \mathrm{mM}$ dithiothreitol) [12,58-60]. The protein concentrations of the cell lysates were measured by Bio-Rad protein assay kits. Equal amounts of protein ( $50 \mu \mathrm{g} /$ lane) were separated by $12 \%$ SDS-polyacrylamide gel electrophoresis (Scie-Plas, Cambridge, UK) and transferred to a polyvinylidene difluoride (PVDF) membrane by electroblotting. The membrane was blocked for $30 \mathrm{~min}$ at room temperature in a blocking reagent (20 mM Tris, $\mathrm{pH} 7.4 ; 125 \mathrm{mM} \mathrm{NaCl} ; 0.2 \%$ Tween $20 ; 5 \%$ non-fat dry milk; and $0.1 \%$ sodium azide) and then incubated for $2 \mathrm{~h}$ with anti-human OPG (1:2000, $0.53 \mu \mathrm{g} / \mathrm{mL})$, RANKL (1:1000, $0.2 \mu \mathrm{g} / \mathrm{mL})$, Ac-H3 (1:500, $0.2 \mu \mathrm{g} / \mathrm{mL})$ and GAPDH $(1: 1000,0.1 \mu \mathrm{g} / \mathrm{mL})$ antibodies. Membranes were washed three times with TBST ( $10 \mathrm{mM}$ Tris, $\mathrm{pH} 7.5 ; 100 \mathrm{mM} \mathrm{NaCl}, 0.1 \%$ Tween-20) for $10 \mathrm{~min}$ each, and then incubated with horse radish peroxidase (HRP)-labeled goat anti-mouse secondary antibody for $1 \mathrm{~h}$. The membrane was then washed 4 times with TBST. Finally, the immunoreactive bands were developed by enhanced chemiluminescence (ECL) reagent and visualized on Fuji X-ray film.

4.7. Effect of Butyrate on OPG, RANKL, 8-Isoprostane, Pro-Collagen I, MMP-2, Osteopontin, Osteonectin and Osteocalcin Secretion and the ALP activity of MG-63 Cells

Cells were treated with butyrate as above (Section 2.2). The culture medium was collected before MTT assay and used for the enzyme-linked immunosorbant assay (ELISA) of OPG, RANKL, 
procollagen I, MMP-2, osteopontin, osteonectin, osteocalcin and 8-isoprostane levels according to the instructions of the ELISA kit. For the assay of ALP activity, MG-63 cells were incubated in medium containing various concentrations of butyrate for 3 days. ALP activity was analyzed by following the procedures of ALP staining kits from Sigma-Aldrich as described previously [61,62].

\subsection{Statistical Analysis}

Three or more independent experiments were performed. The results were statistically analyzed by paired Students $t$-test. A $p$ value $<0.05$ was regarded as indicating a statistically significant difference between groups.

Author Contributions: M.-C.C., Y.-J.C., Y.-H.P. and J.-H.J. conceptualization; C.-C.H., Y.-H.P. and J.-H.J. data curation; Y.-J.C. formal analysis; M.-C.C., Y.-H.P. and J.-H.J. funding acquisition; M.-C.C., J.-H.J. investigation; B.-E.C., C.-C.H., W.-L.H. and J.-H.J. methodology; M.-C.C., Y.-J.C. and Y.-H.P. project administration; Y.-C.L. resources; Y.-H.P. supervision; Y.-C.L., B.-E.C., C.-C.H. and W.-L.H. validation; B.-E.C. visualization; M.-C.C. and J.-H.J. writing-original draft; Y.-J.C., Y.-C.L., B.-E.C., C.-C.H., W.-L.H. and Y.-H.P. Writing-review \& editing

Funding: This study was supported by the Ministry of Science and Technology, Taiwan (NSC102-2314-B-255-003-MY2, NSC102-2628-B-255-001-MY3, NSC101-2320-B-255-002, NSC-100-2314-B-002-094, NSC-101-2320- B-255-002, MOST104-2314-B-255-010-MY3, MOST106-2314-B-002-034-MY2, and MOST1062314-B-002-033-MY2), he Chang Gung Memorial Hospital (CMRPF1H0061, CMRPF1F0071, CMRPF1G0101, CMRPF1G0102, CMRPF3E0021, CMRPF3E0022, CMRPF3E0023, NMRPF3C0091, NMRPF3C0061, CMRPG1B0031, CMRPF170053, NMRPF370033, CMRPF3E0021, NMRPF3B0071, NMRPF3E0041, NMRPF3E0042, NMRPF3E0043, NMRPF3C0093, NMRPF3H0071, NMRPF3H0061, CMRPF1C0011, 1C0012) and the National Taiwan University Hospital (NTUH 101-001937, NTUH102-002259, NTUH101-S1862 \& NTUH102-S2180, NTUH103-S2368, NTUH104-S2658, NTUH106-S3467, NTUH106-UN-001).

Conflicts of Interest: The authors declare no conflict of interest.

\section{References}

1. Yang, L.; Li, Z.; Li, X.; Wang, Z.; Wang, S.; Sasaki, Y.; Takai, H.; Ogata, Y. Butyric acid stimulates bone sialoprotein gene transcription. J. Oral Sci. 2010, 52, 231-237. [CrossRef]

2. Tanner, A.; Maiden, M.F.; Macuch, P.J.; Murray, L.L.; Kent, R.L., Jr. Microbiota of health, gingivitis and initial periodontitis. J. Clin. Periodontol. 1998, 25, 85-98. [CrossRef] [PubMed]

3. Nishihara, T.; Koseki, T. Microbial etiology of periodontitis. Periodontol 2000 2004, 36, 14-26. [CrossRef] [PubMed]

4. Lamont, R.J.; Jenkinson, H.F. Life below the gum line: Pathogenic mechanisms of Porphyromonas gingivalis. Microbiol. Mol. Biol. Rev. 1998, 62, 1244-1263. [PubMed]

5. Holt, S.C.; Kesavalu, L.; Walker, S.; Genco, C.A. Virulence factors of Porphyromonas gingivalis. Periodontol 2000 1999, 20, 168-238. [CrossRef] [PubMed]

6. Isogai, H.; Isogai, E.; Yoshimura, F.; Suzuki, T.; Kagota, W.; Takano, K. Specific inhibition of adherence of an oral strain of Bacteroides gingivalis 381 to epithelial cells by monoclonal antibodies against the bacterial fimbriae. Arch. Oral Biol. 1988, 33, 479-485. [CrossRef]

7. Njoroge, T.; Genco, R.J.; Sojar, H.T.; Hamada, N.; Genco, C.A. A role for fimbriae in Porphyromonas gingivalis invasion of oral epithelial cells. Infect. Immun. 1997, 65, 1980-1984.

8. Wilson, M.; Reddi, K.; Henderson, B. Cytokine-inducing components of periodontopathogenic bacteria. J. Periodont. Res. 1996, 31, 393-407. [CrossRef] [PubMed]

9. Pollanen, M.T.; Overman, D.O.; Salonen, J.I. Bacterial metabolites sodium butyrate and proprionate inhibit epithelial cell growth in vitro. J. Periodontal Res. 1997, 32, 326-334. [CrossRef]

10. Niederman, R.; Buyle-Bodin, Y.; Lu, B.Y.; Robinson, P.; Naleway, C. Short-chain carboxylic acid concentration in human gingival crevicular fluid. J. Dent. Res. 1997, 76, 575-579. [CrossRef]

11. Provenzano, J.C.; Rocas, I.N.; Tavares, L.F.; Neves, B.C.; Sigueura, J.F. Short-chain fatty acids in infected root canals of teeth with apical periodontitis before and after treatment. J. Endod. 2015, 41, 831-835. [CrossRef] [PubMed]

12. Chang, M.C.; Tsai, Y.L.; Chen, Y.W.; Chan, C.P.; Huang, C.F.; Lan, W.C.; Lin, C.C.; Lan, W.H.; Jeng, J.H. Butyrate induces reactive oxygen species production and affects cell cycle progression in human gingival fibroblasts. J. Periodontal Res. 2013, 48, 66-73. [CrossRef] 
13. Morozumi, A. High concentration of sodium butyrate suppresses osteoblastic differentiation and mineralized nodule formation in ROS17/2.8 cells. J. Oral Sci. 2011, 53, 509-516. [CrossRef]

14. Niederman, R.; Zhang, J.; Kashket, S. Short-chain carboxylic-acid-stimulated, PMN-mediated gingival inflammation. Crit. Rev. Oral Biol. Med. 1997, 8, 269-290. [CrossRef]

15. Chen, X.; Wang, Z.; Duan, N.; Zhu, G.; Schwarz, E.M.; Xie, C. Osteoblast-osteoclast interactions. Connect. Tissue Res. 2018, 59, 99-107. [CrossRef] [PubMed]

16. Barreiros, D.; Pucinelli, C.M.; Oliveira, K.M.H.; Paula-Silva, F.W.G.; Nelson Filho, P.; Silva, L.A.B.D.; Kuchler, E.C.; Silva, B.A.B.D. Immunohistochemical and mRNA expression of RANK, RANKL, OPG, TLR2 and MyD88 during apical periodontitis progression in mice. J. Appl. Oral Sci. 2018, 26, e20170512. [CrossRef] [PubMed]

17. Belibasakis, G.N.; Rechenberg, D.K.; Zehnder, M. The receptor activator of NF- $\mathrm{kB}$ ligand-osteoprotegerin system in pulpal and periapical disease. Int. Endod. J. 2013, 46, 99-111. [CrossRef] [PubMed]

18. Belibasakis, G.N.; Bostanci, N. The RANKL-OPG system in clinical periodontology. J. Clin. Periodontol. 2012, 39, 239-248. [CrossRef] [PubMed]

19. Reddi, D.; Brown, S.J.; Belibasakis, G.N. Porphyromonas gingivalis induces RANKL in bone marrow stromal cells: Involvement of the p38 MAPK. Microb. Pathog. 2011, 51, 415-420. [CrossRef]

20. Han, X.; Lin, X.; Yu, X.; Lin, J.; Kawai, T.; LaRosa, K.B.; Taubman, M.A. Porphyromonas gingivalis infection-associated periodontal bone resorption is dependent on receptor activator of NF-kB ligand. Infect. Immun. 2013, 81, 1502-1509. [CrossRef]

21. Jung, I.H.; Lee, D.E.; Yun, J.H.; Cho, A.R.; Kim, C.S.; You, Y.J.; Kim, S.J.; Choi, S.H. Anti-inflammatory effect of (-)-epigallocatechin-3-gallate on Porphyromonas gingivalis lipopolysaccharide-stimulated fibroblasts and stem cells derived from human periodontal ligament. J. Periodontal Implant Sci. 2012, 42, 185-195. [CrossRef] [PubMed]

22. Jeng, J.H.; Chan, C.P.; Ho, Y.S.; Lan, W.H.; Hsieh, C.C.; Chang, M.C. Effects of butyrate and proprionate on the adhesion, growth, cell cycle kinetics and protein synthesis of cultured human gingival fibroblast. J. Periodontol. 1999, 70, 1435-1442. [CrossRef] [PubMed]

23. Chang, M.C.; Tsai, Y.L.; Liou, E.J.; Tang, C.M.; Wang, T.M.; Liu, H.C.; Liao, M.W.; Yeung, S.Y.; Chan, C.P.; Jeng, J.H. Effect of butyrate on collagen expression, cell viability, cell cycle progression and related proteins expression of MG-63 osteoblastic cells. PLoS ONE 2016, 11, e0165438. [CrossRef] [PubMed]

24. Zhang, S.; Bai, J.; Ren, S.; Wang, R.; Zhang, L.; Zuo, Y. Sodium butyrate restores ASC expression and induces apoptosis in LS174T cells. Int. J. Mol. Med. 2012, 30, 1431-1437. [CrossRef] [PubMed]

25. Tailor, D.; Hahm, E.R.; Kale, R.K.; Singh, S.V.; Singh, R.P. Sodium butyrate induces DRP1-mediated mitochondrial fusion and apoptosis in human colorectal cancer cells. Mitochondrion 2014, 16, 55-64. [CrossRef] [PubMed]

26. Ho, Y.C.; Chang, Y.C. Effects of a bacterial lipid byproduct on human pulp fibroblasts in vitro. J. Endod. 2007, 33, 437-441. [CrossRef] [PubMed]

27. Bolognini, D.; Tobin, A.B.; Milligan, G.; Moss, C.E. The pharmacology and function of receptors for short-chain fatty acids. Mol. Pharmacol. 2016, 89, 388-398. [CrossRef] [PubMed]

28. Cushing, K.; Alvarado, D.M.; Ciorba, M.A. Butyrate and mucosa inflammation: New scientific evidence supports clinical observation. Clin. Transl. Gastroenterol. 2015, 6, e108. [CrossRef]

29. Li, M.; van Esch, B.C.A.M.; Henricks, P.A.J.; Folkerts, G.; Garssen, J. The anti-inflammatory effects of short chain fatty acids on lipopolysaccharide- or tumor necrosis factor- $\alpha$-stimulated endothelial cells via activation of GPR41/43 and inhibition of HDACs. Front. Pharmacol. 2018, 9, 533. [CrossRef]

30. Liu, J.; Wang, Y.; Wu, Y.; Ni, B.; Liang, Z. Sodium butyrate promotes the differentiation of rat bone marrow mesenchymal stem cells to smooth muscle cells through histone acetylation. PLoS ONE 2014, 9, e116183. [CrossRef]

31. Chen, T.H.; Chen, W.H.; Hsu, K.H.; Kuo, C.D.; Hung, S.C. Sodium butyrate activates ERK to regulate differentiation of mesenchymal stem cells. Biochem. Biophys. Res. Commun. 2007, 355, 913-918. [CrossRef] [PubMed]

32. Schroeder, T.M.; Westendorf, J.J. Histone deacetylase inhibitors promotes osteoblast maturation. J. Bone Miner. Res. 2005, 20, 2254-2263. [CrossRef] [PubMed]

33. Lee, H.W.; Suh, J.H.; Kim, A.Y.; Lee, Y.S.; Park, S.Y.; Kim, J.B. Histone deacetylase 1-mediated histone modification regulates osteoblast differentiation. Mol. Endocrinol. 2006, 20, 2432-2443. [CrossRef] [PubMed] 
34. Delanty, N.; Reilly, M.; Pratico, D.; FitzGerald, D.J.; Lawson, J.A.; FitzGerald, G.A. 8-Epi PGF2 $\alpha$ : Specific analysis of an isoeicosanoid as an index of oxidant stress in vivo. Br. J. Clin. Pharmacol. 1996, 42, 15-19. [CrossRef] [PubMed]

35. Pratico, D.; Rokach, J.; Lawson, J.; FitzGerald, G.A. F2-isoprostanes as indices of lipid peroxidation in inflammatory diseases. Chem. Phys. Lipids 2004, 128, 165-171. [CrossRef] [PubMed]

36. Sottero, B.; Rossin, D.; Poli, G.; Biasi, F. Lipid oxidation products in the pathogenesis of inflammation-related gut disease. Curr. Med. Chem. 2018, 25, 1311-1326. [CrossRef] [PubMed]

37. Musiek, E.S.; Morrow, J.D. F2-isoprostanes as markers of oxidant stress: An overview. Curr. Protoc. Toxicol. 2005, 24. [CrossRef]

38. Huang, Y.; Zhu, M.; Li, Z.; Sa, R.; Chu, Q.; Zhang, Q.; Zhang, H.; Tang, W.; Zhang, M.; Yin, H. Mass spectrometry-based metabolomics profiling identifies alterations in salivary redox status and fatty acid metabolism in response to inflammation and oxidative stress in periodontal disease. Free Radic. Biol. Med. 2014, 70, 223-232. [CrossRef]

39. Vengerfeldt, V.; Mandar, R.; Saag, M.; Piir, A.; Kullisaar, T. Oxidative stress in patients with endodontic pathologies. J. Pain Res. 2017, 10, 2031-3040. [CrossRef]

40. Khocht, A.; Rogers, T.; Janal, M.N.; Brown, M. Gingival fluid inflammatory biomarkers and hypertension in African Americans. JDR Clin. Trans. Res. 2017, 2, 269-277. [CrossRef]

41. Pradeep, A.R.; Rao, N.S.; Bajaj, P.; Agarwal, E. 8-Isoprostane: A lipid peroxidation product in gingival crevicular fluid in healthy, gingivitis and chronic periodontitis subjects. Arch. Oral Biol. 2013, 58, 500-504. [CrossRef] [PubMed]

42. Parhami, F.; Morrow, A.D.; Balucan, J.; Leitinger, N.; Watson, A.D.; Tintut, Y.; Berliner, J.A.; Demer, L.L. Lipid oxidation products have opposite effects on calcifying vascular cell and bone cell differentiation: A possible explanation for the paradox of arterial calcification in osteoporotic patients. Arterioscler. Thromb. Vasc. Biol. 1997, 17, 680-687. [CrossRef] [PubMed]

43. Ma, E.; Ingram, K.H.; Milne, G.L.; Garvey, W.T. F2-Isoprostane reflect oxidative stress correlated with lean mass and bone density but not insulin resistance. J. Endocr. Soc. 2017, 1, 436-448. [CrossRef] [PubMed]

44. Czerska, M.; Zielinski, M.; Gromadzinska, J. Isoprostanes-A novel major group of oxidative stress markers. Int. J. Occup. Med. Environ. Health 2016, 29, 179-190. [CrossRef] [PubMed]

45. Liu, D.; Xu, J.K.; Figliomeni, L.; Huang, L.; Pavlos, N.J.; Rogers, M.; Tan, A.; Price, P.; Zheng, M.H. Expression of RANKL and OPG mRNA in periodontal disease: Possible involvement in bone destruction. Int. J. Mol. Med. 2003, 11, 17-21. [CrossRef] [PubMed]

46. Rechenberg, D.K.; Bostanci, N.; Zehnder, M.; Belibasakis, G.N. Periapical fluid RANKL and IL-8 are differentially regulated in pulpitis and apical periodontitis. Cytokine 2014, 69, 116-119. [CrossRef]

47. Menezes, R.; Bramante, C.M.; Da Silva Paiva, K.B.; Letra, A.; Carneiro, E.; Fernando Zambuzzi, W.; Granjeiro, J.M. Receptor activator NF-kB-ligand and osteoprotegerin protein expression in human periapical cysts and granuloma. Oral Surg. Oral Med. Oral Pathol. Oral Radiol. Endod. 2006, 102, 404-409. [CrossRef]

48. Fan, R.; Sun, B.; Zhang, C.F.; Lu, Y.L.; Xuan, W.; Wang, Q.Q.; Yin, X.Z. Receptor activator of nuclear factor kB ligand and osteoprotegerin expression in chronic apical periodontitis: Possible association with inflammatory cells. Chin. Med. J. 2011, 124, 2162-2166.

49. Katono, T.; Kawato, T.; Tanabe, N.; Suzuki, N.; Iida, T.; Morozumi, A.; Ochiai, K.; Maeno, M. Sodium butyrate stimulates mineralized nodule formation and osteoprotegerin expression by human osteoblasts. Arch. Oral Biol. 2008, 53, 903-909. [CrossRef]

50. McBeath, R.; Pirone, D.M.; Nelson, C.M.; Bhadriraju, K.; Chen, C.S. Cell shape, cytoskeletal tension and RhoA regulate stem cell lineage commitment. Dev. Cell 2004, 6, 483-495. [CrossRef]

51. Iwami, K.; Moriyama, T. Effects of short chain fatty acid, sodium butyrate, on osteoblastic and osteoclastic cells. Int. J. Biochem. 1993, 25, 1631-1635. [CrossRef]

52. Kim, T.I.; Han, J.E.; Jung, H.M.; Oh, J.H.; Woo, K.M. Analysis of histone deacetylase inhibitor-induced response in human periodontal ligament fibroblasts. Biotechnol. Lett. 2013, 35, 129-133. [CrossRef] [PubMed]

53. Iida, T.; Kawato, T.; Tanaka, H.; Tanabe, N.; Nakai, K.; Zhao, N.; Suzuki, N.; Ochiai, K.; Naeno, M. Sodium butyrate induces the production of cyclooxygenases and prostaglandin E2 in ROS17/2.8 osteoblastic cells. Arch. Oral Biol. 2011, 56, 678-686. [CrossRef] [PubMed] 
54. Chang, M.C.; Lee, J.J.; Chen, Y.J.; Lin, S.I.; Lin, L.D.; Liou, J.W.; Huang, W.L.; Chan, C.P.; Huang, C.C.; Jeng, J.H. Lysophosphatidylcholine induces cytotoxicity/apoptosis and IL-8 production of human endothelial cells: Related mechanisms. Oncotarget 2017, 8, 106177-106189. [CrossRef]

55. Chang, M.C.; Chan, C.P.; Wang, Y.J.; Lee, P.H.; Chen, L.I.; Tsai, Y.L.; Lin, B.R.; Wang, Y.L.; Jeng, J.H. Induction of necrosis and apoptosis of KB cancer cells by sanguinarine is associated with reactive oxygen species production and mitochondrial membrane depolarization. Toxicol. Appl. Pharmacol. 2007, 218, 143-151. [CrossRef] [PubMed]

56. Chang, M.C.; Chen, L.I.; Chan, C.P.; Lee, J.J.; Wang, T.M.; Yang, T.T.; Lin, P.S.; Lin, H.J.; Chang, H.H.; Jeng, J.H. The role of reactive oxygen species and hemeoxygenase- 1 expression in the cytotoxicity, cell cycle alteration and apoptosis of dental pulp cells induced by BisGMA. Biomaterials 2010, 31, 8164-8171. [CrossRef]

57. Sooampon, S.; Manokawinchoke, J.; Pavasant, P. Transient receptor potential vanilloid-1 regulates osteoprotegerin/RANKL homeostasis in human periodontal ligament cells. J. Periodontal Res. 2013, 48, $22-29$. [CrossRef]

58. Chang, M.C.; Wu, H.L.; Lee, J.J.; Lee, P.H.; Chang, H.H.; Hahn, L.J.; Lin, B.R.; Chen, Y.J.; Jeng, J.H. The induction of prostaglandin E2 production, interleukin-6 production, cell cycle arrest, and cytotoxicity in primary oral keratinocytes and $\mathrm{kB}$ cancer cells by areca nut ingredients is differentially regulated by MEK/ERK activation. J. Biol. Chem. 2004, 279, 50676-50683. [CrossRef]

59. Jeng, J.H.; Ho, Y.S.; Chan, C.P.; Wang, Y.J.; Hahn, L.J.; Lei, D.; Hsu, C.C.; Chang, M.C. Areca nut extract up-regulates prostaglandin production, cyclooxygenase- 2 mRNA and protein expression of human oral keratinocytes. Carcinogenesis 2000, 21, 1365-1370. [CrossRef]

60. Chang, H.H.; Guo, M.K.; Kasten, F.H.; Chang, M.C.; Huang, G.F.; Wang, Y.L.; Wang, R.S.; Jeng, J.H. Stimulation of glutathione depletion, ROS production and cell cycle arrest of dental pulp cells and gingival epithelial cells by HEAM. Biomaterials 2005, 26, 745-753. [CrossRef]

61. Chang, H.H.; Chang, M.H.; Wu, I.H.; Huang, G.F.; Huang, W.L.; Wang, Y.L.; Lee, S.Y.; Yeh, C.Y.; Guo, M.K.; Chan, C.P.; et al. Role of ALK5/Smad2/3 and MEK/ERK signaling in transformning growth factor-beta 1-modulated growth, collagen turnover, and differentiation of stem cells from apical papilla of human tooth. J. Endod. 2015, 41, 1272-1280. [CrossRef] [PubMed]

62. Chang, Y.C.; Chang, M.C.; Chen, Y.J.; Liou, J.U.; Chang, H.H.; Huang, W.L.; Liao, W.C.; Chan, C.P.; Jeng, P.Y.; Jeng, J.H. Basic fibroblast growth factor regulates gene and protein expression related to proliferation, differentiation, and matrix production of human dental pulp cells. J. Endod. 2017, 43, 936-942. [CrossRef] [PubMed]

(C) 2018 by the authors. Licensee MDPI, Basel, Switzerland. This article is an open access article distributed under the terms and conditions of the Creative Commons Attribution (CC BY) license (http:/ / creativecommons.org/licenses/by/4.0/). 